\title{
The Operatic Styles in Jörg Widmann's Viola Concerto
}

\section{Kheng K. Koay}

Jörg Widmann is widely acclaimed as both a composer with striking originality in composing and a great clarinetist. His musical handling constantly engages with new musical ideas and approaches. In his dramatic and brilliant writing, combined with imaginative ideas, Widmann has created a remarkable Viola Concerto (2015). The concerto is linked with disparate ideas, designed in an unconventional manner, in which Widmann has turned a traditional concerto performance into something full of inventive effects and interesting sonorities, conveying not only his imaginative message, but also giving listeners an unusual, fresh and unique concert experience. This study addresses Widmann's operatic approach found in this composition.

Throughout his creative career Widmann has often challenged himself in his own writing, exploring musical mixtures for sources and ideas that may not necessarily belong together. He explains that "com-posing - things which at first sight do not seem to belong together, but I put them together, maybe I force them together and maybe they still don't seem to belong, but it's com-posing." $\mathrm{He}$ also thinks that "composition is the written improvisation."

The Viola Concerto was a commissioned work from the Orchestre de Paris, the Swedish Radio Symphony Orchestra and the Bavarian Radio Symphony Orchestra. It was written for Antoine Tamestit. Widmann's highly individual sound-world is clearly heard in the Concerto. The necessary sounds are represented in the score with new symbols and additional instructions to suit the purpose of Widmann. The music ranges across an emotional continuum, from rage to sorrow. Musical contrasts are heard in the composition for intended purposes. The music runs from clashing dissonances, soaring viola lines, to melancholic lyrical beauty. It is as if the music is straddled between two separate worlds; at times the idiom is surprisingly experimental and complex, at other times it is

1 Quoted from Asher Ian Armstrong, “Jörg Widmann's Jagdquartett”, Tempo, 70.276 (2016): 25.

2 Quoted from Elisabeth Schwarz, "I encourage them to write the impossible': Jörg Widmann on his life as a clarinetist and composer”, Bachtrack, May 23, 2018, available online at https://bachtrack.com/interview-joerg-widmann-clarinet-composing-weber-may-2018 (accessed on June 4, 2019) 
romantic and lyrical. Different levels of emotions are expressed throughout the composition. To some extent, his music conveys not only the events of an abstract "story" but also the emotions bound up in the "story".

A wide variety of playing techniques are used; vigorous pizzicati, shivering glissandi, and further experiments in sound are explored in the music, creating a rich timbre and atmosphere in the composition. Tensions are created through different manners. Several climax moments are designed and presented differently from conventional orchestra music. In the concerto Widmann has created an impression that he has more to tell his listeners in the composition, which is worth the effort to explore in this study. Interesting and unusual setups are included, not only creating dramatic effects, but also shaping the structure of the music.

Indeed, hearing the music does not necessarily entail understanding the purpose of the composer. Other aspects are experimented with in the Viola Concerto. Apart from his exploration of relationships between sounds such as vocal and instrument, Widmann also ventures into facial expressions and physical gestures and movements in relation to the musical sound. He is making the music as dramatic and as theatrical as possible. In the orchestra music Widmann has ways of relating sound colors to ideas, gestures and images, providing an abstract visual experience and giving new possibilities in presenting a concerto. His artistic goals are to create both aural and visual effects in his music and to invite listeners to a deeper engagement with the musical events in the composition, despite the fact that visual effects are used to enhance the excitement of the music.

The unusual approach in the concerto is how Widmann prolongs his involvement with the operatic fashion in the music: every forward development in Widmann's "story" in an abstract way makes the composition into a complete whole. There is also a story-telling quality in the music. An orchestra setup chart is provided in the published score with specific details indicating the more significant stage directions of the solo violist throughout the performance. This is designed beyond the confined tradition of solo concerto performance one often encounters. Each musical event happens differently in a different stage "location", which also shows Widmann's attempt to theatricalize his concerto. In the composition, it is as if the soloist is being treated as a protagonist who moves imaginarily in Widmann's music “story".

There are also times when Widmann depicts a soprano protagonist in the Viola Concerto. Indeed, the composition is designed with a similar idea to an opera, though without the inclusion of costume, scenery, dramatic lighting effects, an obvious plot and a curtain-raiser. Widmann lets his music run wild, trying to 
bring to the public an adventure in a synthesis of two genres of musical styles. It is this idea that also gives the composition a unique character.

Interestingly, Widmann is making a concert-hall performance into a potential "opera". Physical movements are emphasized, creating a particular character in the music. In the Viola Concerto, not only does Widmann design the solo violist as the lead character who moves around the orchestra on the stage, but there are also settings of musical dialogues between the soloist and different instruments to create imaginary "scenes" and theatrical gestures on the attractive surface. The dramatic sound palette is also inherent in the music to enhance the staged visual effects. The composition certainly projects abstract ideas and imagery of something inexplicable, and feelings beyond words.

As in many concerti, Widmann includes quasi-cadenza passages in the Viola Concerto, but he does not simply build upon tradition; instead, he introduces them in different ways. The composition is beyond the expectations of his audience. Widmann's music is able to express a strong emotional sense; nevertheless, it is playful and full of surprises. Different musical dialogue manners are heard in the music. There are combinations of musical and operatic ways of acting and interacting in the music, with different instruments heard in the manner of a dialogue.

\section{Widmann's Approach in Music}

Being an active performer, Widmann has performed throughout the world in a wide range of works from different periods, ranging from Bach to his own contemporaries. On the other hand, he is also a composer whose music is full of originality, with suggestive and creative ideas. He has written in a variety of genres: operas, orchestral works, chamber music, instrumental pieces, including piano, vocal music, and symphonic vocal works. In balancing his career between a performer and composer, Widmann relates back to music life in the past centuries:

If we'd had this conversation in the middle of the 18th century, it wouldn't have been worth mentioning, because everyone would have played at least one instrument, composed and conducted. It was only in the middle of the 19th century that it started to differ. Suddenly there was this maestro type, the conductor. At the same time the virtuoso type evolved, with Paganini, with Liszt. And then, in his quiet chamber, there was this quirky or brilliant composing person. For me, this entity never stopped existing, even if it's more difficult in practice. ${ }^{3}$

3 Ibid. 
It is claimed that "the various aspects of musical creation are for him [Widmann] a self-evident unity: he thinks, feels, performs, and writes without borders." ${ }^{4}$ Anything can be an inspiration for Widmann.

It can be stories, an encounter, it can be a love - this was the case for a work I wrote for the Vienna Philharmonic, Teufel Amor. Personal things play a role, literature, poetry, painting, sculptures. There's almost nothing that couldn't inspire me. ${ }^{5}$

Widmann's imaginative fantasies are freely experimented with in his music. Inspired by many composers of the 19th century, he also explores subjects that are related to the exotic. Widmann provides a description of his Viola Concerto, in which he evokes a connection to a fantasy:

In my Viola Concerto, the setting is transported for long periods to a utopia land; at the beginning to a foreign and tentative sphere, inhabited only by viola pizzicato of all possible and impossible variants; then a wistful song from an imaginary oriental fairytale world; finally a crash into artistic-absurd cascades of virtuosity introducing the heart of the piece; a painful intimate swan song in a submerged world that will only be pulled into a dazzling reality in the final bars. ${ }^{6}$

Moreover, Widmann has been attracted to fairy tales. In his Once upon a time... (2015) for clarinet, viola and piano, Widmann says that, "as far as I can remember, I have always been fascinated with fairy tales... Fairy tales were however also a source of unrest for me as a seismograph of mankind's underlying primal fears and desires."7

On the other hand, Widmann's music shows his acceptance of impulses from tradition. Among the many composers of the past centuries, Widmann has been deeply attracted to the innovative sound color found in Weber's music.

As a clarinetist I have loved Carl Maria von Weber's music since my youth, and as a composer I admire it. His musical language is unique and his orchestration

4 Pia Steigerwald, "Examination - Drifting, Freedom - Postulation. Then Once Again Freedom”, in booklet of "Jörg Widmann: Drittes Labyrinth, Polyphone Schatten", perf. WDR Sinfonieorchester. 2018 Wergo, WER 7369 2. Compact dics., LC 00846.

5 Ibid.

6 Jörg Widmann, "Work of the Week - Jörg Widmann: Viola Concerto", Schott, October 26, 2015; available online at https://en.schott-music.com/work-of-the-week-jorg-widmann-viola-concerto/ (accessed on June 8,2019)

7 Jörg Widmann, “One upon a time...”, Schott, available online at https://en.schott-music.com/ shop/es-war-einmal-no306700.html (accessed on June 28, 2019) 
skills simply brilliant. Besides Mozart, no one else ever understood the character of the clarinet and the secrets of its erogenous zones as did Weber. ${ }^{8}$

Widmann describes Weber's innovations above all the other composers:

I would put him [Weber] on a very high level, like the composer of his time and after him did. Debussy and Stravinsky weren't especially keen on German music - out of an anti-Wagnerism - but they appreciated Weber... For me, it was Weber who brought these innovations to the Romantic orchestra, the orchestra technique. He wrote with a daring tonality, way above Wagner. ${ }^{9}$

Widmann always likes "the idea of classical music being combined with modern music. [That is] because I am convinced that the audience sees things differently." 10 The performances of his music are often placed alongside performances of Romantic composers such as Schumann, Mendelssohn, Mozart, Weber and many others. Widmann has a strong affection for past composers, and his music recalls a connection with past music traditions. "I love the music of all times. To me, a Schumann piece, a Brahms piece, a Purcell piece can be equally contemporary as a piece that is written in our time...," said Widmann. ${ }^{11} \mathrm{It}$ is claimed that Widmann's music "is a dialogue, homage and continuation of the essential concerns of the music he loves most: Beethoven, Schumann, Schubert, Mozart, Mahler, Berg - as well as Rihm and Lachenmann." ${ }^{12}$

In his Con Brio (2008), which is an orchestral homage to Beethoven, Widmann refers to the characteristics of Beethoven's Symphonies No 7 and No 8. His Idyll and Abyss: Six Schubert Reminiscences (2009) is a homage piece to Schubert. Widmann's love for Schubert's music can also be heard in his Octet. "My great love for Schubert, finally managed to inspire me to write my own Octet." ${ }^{13}$ Similarly, Schumann also has had an influence on Widmann's piano

8 Jörg Widmann, "Mozart, Weber, Widmann: Klarinetten-Konzerte”, Perf. Deutsches SymphonieOrchester Berlin, 2015 Orfeo, C 897151 A. Compact disc., LC 8175.

9 Jörg Widmann, "Work of the Week - Jörg Widmann: Viola Concerto".

${ }^{10}$ Jörg Widmann, "Jörg Widmann Talks: Suntory Hall International Program for Music Composition No. 41 Theme Composer", Suntory, June 14, 2018; available online at https://youtu. be/MP7jZ4rYtRQ (accessed on June 30, 2019)

${ }^{11}$ Quoted from Jonathan Blumhofer, "Preview/Interview: Jörg Widmann's 'Trauermarsch' - An Idea of Paradise", The Arts Fuse, October 3, 2016; available online at http://artsfuse.org/150834/ previewinterview-jorg-widmanns-trauermarsch-an-idea-of-paradise/ (accessed on May 8, 2019)

12 Tom Service, “A Guide to Jörg Widmann's Music", The Guardian, Oct 8, 2012; available online at https://www.theguardian.com/music/tomserviceblog/2012/oct/08/jorg-widmann-contemporary-music-guide (accessed on May 8, 2019)

${ }^{13}$ Verena Krauledat, "Schubert - Widmann: a special relationship”, in booklet of "Schubert, F: Octet/ Widmann, J: Octet,” 2010 Deutschlandradio/ Avi-Service for music. Compact disc., LC 15080. 
writing. In an interview he claims that "I learned a lot from Schumann's piano writing and would even say that my piano music would be unthinkable without his." 14

What also has attracted Widmann is distinctive musical creativity; he is always interested in and draws from the individual musical writing styles of composers.

I understand that one wants to label things and categorize them, but even in the music of the past, I'm not interested in the Russian School, the Munich School, the Paris School - I'm interested in the personal language of Debussy, the personal language of Mahler. When we hear something or we see a painting or we hear a poem we try to link it to something we already know, and that's very understandable..$^{15}$

Widmann's life has also been inextricably linked between being a clarinetist and a composer. "A big part of what I write has to do with the fact that I'm a musician, a clarinetist, myself," he further says "and that I'm on stage and that I perform regularly with other people - chamber musicians, orchestras, other people. And I think it's always been like that since I started playing the clarinet at the age of seven. For me, [mixing old and new, different styles, etc.] was very natural. ${ }^{16}$

He also claims that "as a player, I'm in touch with [...] masterworks every day. I love them! So I write pieces about my love." ${ }^{17}$ In Lied (2003, rev. 2009) for orchestra, for instance, we hear "a sumptuous study of Schubertian melody, echoes of Mahler, Strauss, and early Schoenberg (not to mention Schubert and Wagner) abound." ${ }^{18}$ His Partita (2017-2018) for large orchestra, Widmann calls "a declaration of love - for the music of Mendelssohn. And of Bach," and "the whole concept of 'Partita' is to link the music of those two." ${ }^{19}$ Au cour de Paris (2017) for orchestra draws from "three famous pieces associated with the

${ }^{14}$ Luisa Imorde, “Gespräch zwischen luisa imorde und Jörg Widmann”, in booklet of “Zirkustänze: Robert Schumann and Jörg Widmann” perf. by Luisa Imorde (piano). 2016 Deutschlandradio/ ARS Producktion. Compact disc., LC 06900.

15 Quoted from Asher Ian Armstrong, "Jörg Widmann's Jagdquartett", 25.

${ }^{16}$ Quoted from Jonathan Blumhofer, "Preview/Interview".

${ }^{17}$ Sebastian Black, "The Art of Reminiscent: Thought on Jörg Widmann and Musical Meaning”, Serenade, July 12, 2018; available online at https://serenademagazine.com/series/know-your-composer/the-art-of-reminiscence-thoughts-on-jorg-widmann-and-musical-meaning/ (accessed on May 8, 2019)

18 Blumhofer, "Preview/Interview".

${ }^{19}$ Keith Powers, "For the BSO, Composer Jörg Widmann's 'Partita' offers Connection and Surprise", Wbur, March 26, 2018; available at https://www.wbur.org/artery/2018/03/26/bso-jorg-widmann-partita (accessed on May 8, 2019) 
city: the famous cancan from Jacques Offenbach's Orphée aux enfers (premiered at the Théâtre des Bouffes-Parisiens, Paris, in 1858), and two songs made famous by Edith Piaf, Sous le ciel de Paris and La vie en rose." ${ }^{20}$

Widmann also embraces Western music but of the non-European sound world. His diversity in stylistic writing encompasses music beyond the Westernart-music canon, such as in his Fantasie (1993) for clarinet solo, in which there are moments that draw on aspects of jazz, and in scene 2 of Babylon (2011-2012, rev. 2018), in which "referenced Viennese operetta, Sousa marches, Dixieland and big band jazz, among other sources" 21 can be heard. Apart from Western art composers, Widmann is a fan of Miles Davis. ${ }^{22}$ "His [Davis'] music, his playing, to me, he is an innovator like Schoenberg, like Stravinsky, like Picasso."23 Widmann's early work Nightpiece (1998) for clarinet, cello and piano is described as "between 'jazzy-secco' and the 'Spieluhr' solo." ${ }^{24}$ The imitation of other nonWestern musical styles is also heard in the Viola Concerto. Other than musical styles, non-Western instruments are employed for their unique sound colors. For instance in his Babylon, seven shofars are used.

Widmann often experiments with titles, ideas and techniques of vocal music in his instrumental ensembles and orchestral works. This can be seen in the title of his orchestral works such as Lied (2003, rev. 2009), Chor (2004), Antiphon (2007-2008), and instrumental works Liebeslied (2010) for eight instruments, Aria (2015) and others. His Aria for string ensemble "is an aria in the literal sense: the multiple divided strings give the impression of imaginary voices" and "the roles of vocal protagonists are undertaken by the concertante violin and viola," said Widmann. ${ }^{25}$ In his Messe, Widmann substitutes the solo vocalists and chorus for a large orchestra. He describes that,

The instrumental singing is the topic of my earlier orchestral works "Lied" and "Chor". There is no singer or choir performing; the orchestra is singing, reciting and declaiming. That's how it is with Messe: The musicians are the protagonists:

${ }^{20}$ Black, "The Art of Reminiscent".

${ }^{21}$ Malcolm Miller, "Munich, Bayerische Staatsoper: Jörg Widmann’s 'Babylon”, Tempo, 67.264 (April 2013): 71.

${ }^{22}$ Wolfgang Stähr, "Bards and Beats: Music by Mendelssohn and Widmann", in booklet of "Widmann: 180 beats per minute, Fantasie; Mendelssohn: Sinfonie No. 3 'Schottische”, perf. Irish Chamber Orchestra. 2018 Orfeo, C 945181 A. Compact disc., LC 8175.

${ }^{23}$ Jörg Widmann, “Jörg Widmann on Playing Clarinet and His Musical Influences”, 92 Y Performing Arts - Concerts, April 11, 2013; available online at https://www.youtu.be/3CAvr9jtqMY (accessed on June 30, 2019)

24 "Nightpiece". Schott, available online at https://en.schott-music.com/shop/nachtstueck-no176396. html (accessed on June 28, 2019)

25 Jörg Widmann, “Aria," Schott, July 2016; available online at https://en.schott-music.com/shop/ aria-no332225.html (accessed on May 24, 2019) 
Solos, choir and orchestra rolled into one. For example, there is an antiphony between choir and organ in the "Monodia" of the "Kyrie", but no choir or organ is really involved. In central liturgical passages, for example at the beginning of the "Kyrie" or the "Gloria", the notes appear like a gigantic choral score. Every musician "sings" the particular mass text on his $[$ sic $]$ instrument. $^{26}$

Not only does Widmann fuse different stylistic writings, but also genres in many of his compositions. Apart from the Viola Concerto, his String Quartet No. 5, Versuch über die Fuge (2005), for instance, adds a soprano voice singing the text from Vulgate. This interest has remained a constant feature in his compositions. The use of a vocal finale in an instrumental work has a precedent in Beethoven's Symphony No. 9, and Schoenberg also included a soprano voice in his String Quartet No.2.

\section{Viola Concerto}

The composition is divided into five sections: I. Pizzicato: Molto rubato - Più mosso, II. Sehr langsam - Calmo, III. Poco vivo subito, IV. Toccata: Presto, V. Aria: Molto adagio. As such, it can also be seen as a five-act drama. The overall structural design of the composition is constructed by a stark and major oppositional contrast of sound colors that divides the piece into two main parts: the taping sound and the arco bowing. The music begins with a solo viola instrument in tapping sound on the fingerboard and drumming fingertips on the chinrest and moves to the bowing sound, which is first introduced toward the end of the Pizzicato: Molto rubato - Più mosso.

Although there is no obvious motivic material that connects the music throughout the composition, and each section/act has its own individual character that differs from the previous, they are carefully and creatively connected through transitional passages, particularly from second to third, and fourth to fifth sections/acts. Moreover, at the surface level, one section/act links to another through the design of Widmann's abstract and imaginary "story".

To make greater imaginative images and events of Widmann's fantasy, musical dialogue - which is a tradition of classical music, especially typical in the concerto's relationship between soloist and orchestra-is emphasized in the Viola Concerto. The word "Concerto" is believed to mean "to dispute" or "to work together" which derives from the Latin concertare, and "to agree" or "to get together" in Italian. ${ }^{27}$ Different instrumental characters "say" and "respond," "agree" and "disagree" to one another in an imaginative and abstract way. Nevertheless,

\footnotetext{
26 "Work of the Week - Jörg Widmann: Messe", Schott, July 4, 2016; available online at https:// en.schott-music.com/work-week-jorg-widmann-messe/ (accessed on May 24, 2019)

${ }^{27}$ Denis Arnold and Timothy Rhys Jones, "Concerto". Oxford Music Online; available online at
} 
musical dialogue does not occur merely in concertos; since the 18th century it was also experimented with in other instrumental music genres in ways that show close relevance to characteristics found in an opera, a drama or a play.

To create music as a form of opera in his Viola Concerto, Widmann offers his own version of presenting the musical dialogue. He seems to be a storyteller designing different musical characters, sound colors, gestures and expressions from moment to moment and from "act" to "act", telling a story in his own abstract way. The initial instrumental dialogue is heard in the first act when there is a sudden pop-up of bongos cutting off the flow of the drumming sound produced by the soloist on his/her viola. In addition to the music, the physical character of the soloist has his/her role in the composition: an act of facial gesture in the soloist shows the unexpected, abrupt disruption by the bongos. The two instruments respond to each other back and forth twice without other instrumental colors. Widmann attempts to project an image of a short musical dialogue between the two instruments, and their "conversation" may sound like a disagreement. The event does not stay long; other instruments are added as the music progresses, which indicates a continuation of the "story".

On the other hand, it is not surprising that Widmann's ideas and experience of operatic composing may have spilt over to his concerto. His intimate familiarity with operatic conventions came from over the course of writing several operas such as K(l)eine Morgenstern-Szene (1997), Das Echo (2000-2001), Das Gesicht im Spiegel (2002-2003, rev. 2010), Monologe für zwei (2002), Babylon (2011-2012, rev. 2018) prior to the Viola Concerto. Moreover, Widmann encountered opera at a young age. "My parents took us to concerts and to the opera; it was kind of our childhood." ${ }^{28}$ He has been attracted to Mozart's operas, especially in his instrumentation. ${ }^{29}$ His Quintet (2006) for oboe, clarinet, horn, bassoon and piano is "a deliberate tribute to Mozart's work for the same instrumentation (KV 452)."

Another interesting dialogue and dramatic moment occurs beginning at measure 241 in act two after a quasi-cadenza passage. Widmann incorporates a different sound color and expression between the two instruments. A seemingly angry tuba, which is marked with sffffz and strong accented markings on individual, short note-value, barks at the solo violist loud enough to make him

http://www.oxfordmusiconline.com/subscriber/article/opr/t114/e1550?q=concerto\&search=quick\&pos=3\&_start=1\#firsthit (accessed on March 15, 2017)

28 Asher Ian Armstrong, “Jörg Widmann's Jagdquartett”, Tempo, 70.276 (2016): 22.

${ }^{29}$ Rainer Karlitschek and Hanspeter Krellmann, "Interview: Jörg Widmann über Das Gesicht im Spiegel', Schott; available at file://C:/Users/adm/Downloads/Das_Gesicht_im_Spiegel_-_ Interview.pdf (accessed on June 20,2019)

30 "Quintet", Schott; available online at https://en.schott-music.com/shop/quintett-no227268.html (accessed on June 29, 2019) 
jump. The passage appears to describe an event in the fairytale world. The angry tuba is played against the glissandi solo viola sound color, giving an obvious and interesting dialogue and responses between the two instruments.

There is an unexpected theatrical act seen in act three, which is written in a somewhat cadenza-like passage in high technical skill virtuoso. It is a passage presented with energetic force, with a gradual increase in texture and tempo as the music progresses. The rapid running notes also project a frantic mood and ultimately leads to a loud, fury vocal scream, which has created an interesting sudden transformation from instrumental sound to vocal voice, changing the instrumental soloist into a role of protagonist. The combined force of instrumental and vocal voice also reveals the experimental character of Widmann attempting to fuse theatrical elements into his instrumental composition.

To Widmann, every movement of an instrumentalist can be a theatrical gesture. In his Viola Concerto, for instance, Widmann describes that "the dramatic element is inherent in the music, in its various guises and moods, for instance in the episode with the raging tuba." ${ }^{31} \mathrm{He}$ further claims that

it made me aware that for a trombone player, for instance, the way he prepares to sound his [sic] instrument, lifts it to his lips and takes a breath, can already be seen as a theatrical gesture. The ordinary task of playing an instrument is theatrical in itself. ${ }^{32}$

There are a few surprising events found in the music. For instance, a playful event of an act of a viola "tuning up" session occurs in the music towards the end of act one. Instead of the concert master, the solo violist leads the "tuning up" session, walking among other performers in the center of the stage. Traditionally, a one-note tuning up session occurs right before the start of an actual performance. Here, sustaining pitches D4 and A4 (based on middle C as C4) on D and A strings, are used in Widmann's unexpected moment of a "tuning up" session. (Example 1).

Another interesting moment happens when the soloist is bowing and simultaneously singing without words in low-pitched vocables towards the end of act two, giving a different sound effect. This demonstrates one approach of how Widmann incorporates and experiments with vocal sounds in the concerto genre.

${ }^{31}$ Jörg Widmann, "Interview with the composer Jörg Widmann", in booklet of "Widmann, J: Viola Concert/ 24 Duo (excerpts)/ String Quartet No. 3”, perf. Antonie Tamestit (viola), Symphonieorchester des Bayerischen Rundfunks, cond. Daniel Harding. 2018 Harmonia Mundi. Compact disc., HMM902268DI

32 Ibid. 


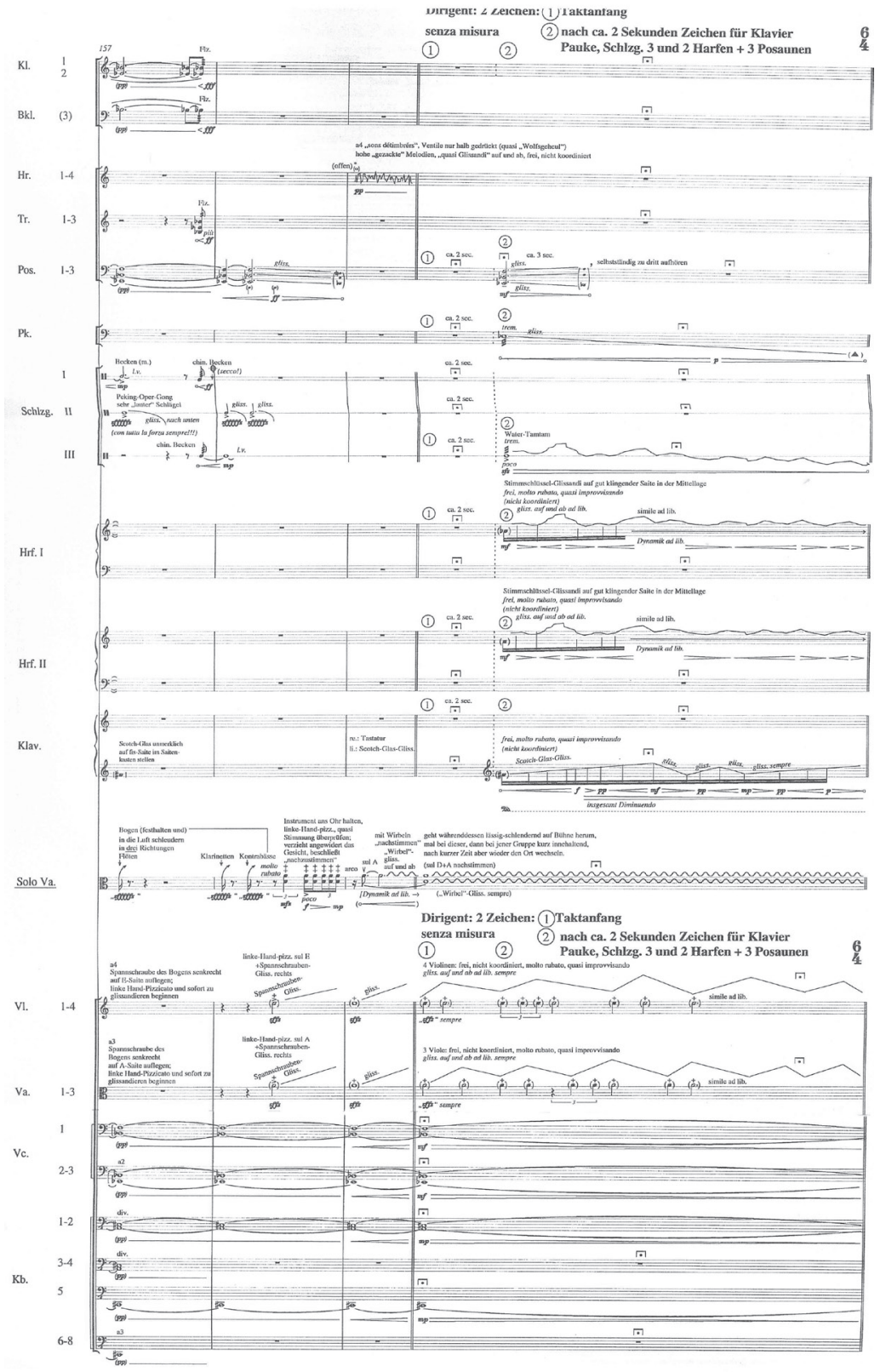

Example 1 
Other intriguing theatrical and dramatic effects occur in act three where there is a moment of vocal screaming by the soloist and an orchestra sound gesture that does not happen in a regular piece, but is creatively designed to catch the attention of the audience. The exaggerated screaming emotion is assisted by facial gesture for visual effect. Not only does the fortissississimo (fff) vocal screaming moment reflect the frustration and intense innermost human feeling of the soloist or a protagonist, but it also intensifies the tension of the music. The screaming is immediately followed by striking, thick texture, chaotic, restless orchestral sounds in small note-values and fast tempo, descending from the high pitch register to the low pitch register. The falling orchestra sound not only releases the tension of the music, but also it is as though projecting the emotional collapse of the soloist. The thickness of texture and intensity, and the forceful energy of music is soon leading to the forth section without a break.

Widmann always has a strong imaginative power. Diverse imaginative images are created through different performing presentations in the composition to attract the attention of the audience. This includes musical characters that are conveyed directly by physical movements and facial expressions to produce visual and theatrical effects. To achieve the precise interpretation and gestural movements there are also instructions indicated in the score. For example, towards the end of the first act an instruction of "fling bow upwards (holding firmly)" is given to the soloist indicating a martial raising bow gesture, in which the soloist is "engaged in a ritual: first 'forging the sword', then thrusting it into the air." 33 This event is preceded by a silent moment of the solo viola, in which he/she is preparing for the unexpected raising bow gesture. The gesture is articulated by the sound of a Peking opera gong, linking the gesture and sound together. The work brings the listener close to an operatic or dramatic experience in orchestral music. Similarly, the musical characters that are conveyed directly by the physical actions of the players can be seen at the beginning and ending of Widmann's String Quartet No. 3 "Hunting Quartet" (2003). The composition begins when the players whip their bows with martial yells ("Hey!") and ends when the players whip their bows with shouts.

The exceptional emotional moments heard in the solo viola that occur in sections/acts two and five are as if the composer had in mind writing for a vocal solo. Nevertheless, instead of vocal presentation of the melodies, the instrument "sings". This not only occurs in Widmann's compositional writing, but also in his performing. His performance of Shumann's clarinet Fantasiestücke is heard

33 Ibid. 
as echoing, like that of Dichterliber, as "Widmann's clarinet sings like a great vocalist." 34

In his concerto, both solo melodic lines begin after a pause indicating an end of the previous event and the beginning of a new act. In the second act, there are stepwise motions with occasional leaps of not more than a fifth in narrow pitch range; this memorable, lyrical melodic line reflects a mood as if it is a song or an aria in which the protagonist expresses his or her innermost thoughts and feelings, like a soliloquy in a play. Moreover, to set up for an imaginary "scene" percussion instruments such as a rainmaker, metal chimes and a triangle and other instruments, including harps, are employed to create a surrounding atmosphere.

Although Widmann writes the theme of the second act with an oriental style in mind-as he described it: "a wistful song from an imaginary oriental fairytale world"35 - the opening of the melody that begins at 173 in the solo viola shares some similarity with the North American folk and gospel song, Wayfaring Stranger, of which its origin is far from exact. Not only are both melodies written in an arch form at the opening, but also in similar intervallic patterns. Perhaps it is a way Widmann "dialogues" with the past folk song, providing a new way of listening to it. He once explained that, "I'm very interested in a dialogue, but not in a nostalgic way, looking back and saying, well, it was so nice in the past. A dialogue is not always only agreeing with each other. Sometimes it's a questioning of the other one. ${ }^{36}$ It is also an attempt by Widmann to have his audience hear the past in a different way.

There are also some brief moments where the idea of the use of background extras springs to mind in the music. An example can be heard in section/act two beginning at measure 199, where wide leaps, fast running notes in triplets and quintuplets, and intervals such as thirds and seconds, are employed in the bass and contrabass clarinets in short-note values. These musical gestures are presented in groups of 2 to 14 notes with rests inserted in between, imitating the role of background actors who are having their short "conversation" that is usually found in a movie. Moreover, various levels of dynamic markings such as pianississimo, pianissimo, mezzo piano, sforzanto (sffz) and many others are used to create the manner of "conversational" activity of background extras in the music.

${ }^{34}$ George Grella, "Beautiful playing by Widmann, Uchida makes for a memorable recital at Zankel Hall”, New York Classical Review, April 3, 2017; available online at http://newyorkclassicalreview. com/2017/04/beautiful-playing-by-widmann-uchida-makes-a-memorable-recital-at-zankel-hall/ (accessed on May 8, 2019)

35 Jörg Widmann, "Work of the Week - Jörg Widmann: Viola Concerto".

${ }^{36}$ Quoted from David Weininger, "Widmann Embraces Dialogue of Past and Present", Yellowbarn, July 31, 2015; available online at https://www.yellowbarn.org/blog/widmann-embraces-dialogue-past-present (accessed on May 8, 2019) 


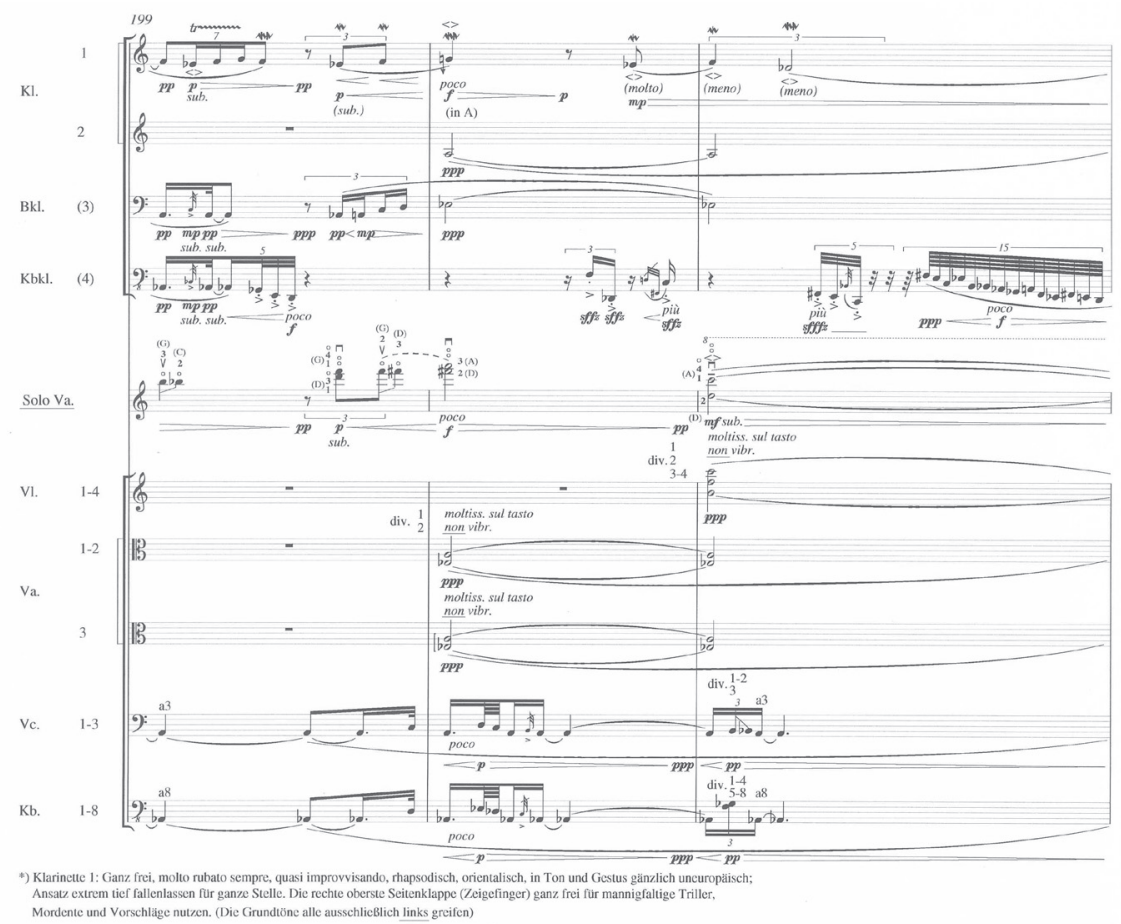

Example 2

Such writing has added effectiveness to his music, evoking an imagery "scene" in the section/act. In the concerto, the background extras play an accompaniment role, while the clarinets do the "singing" (Example 2). Background extras (supernumerary) are also found in an opera, especially in a grand opera, though they appear in a non-speaking or non-singing (silent) activity.

The idea of communicating through singing aria and recitative, which is found in the characters of opera, is used in Widmann's concerto. In the concerto the expressive and beautiful aria melodic line of the solo viola in the last act draws on the arias of the traditional opera, particularly in the nineteenth century. A different setting is introduced here. Widmann describes this melody as "a painful intimate swan song" in which can be indicated "a farewell appearance or final act of pronouncement," and as "a song of great sweetness said to be sung by a dying swan." ${ }^{37}$ The soloist is being treated as a highly trained lyric soprano

37 “Swan Song”, Merriam-Webster, available online at https://www.merriam-webster.com/dictionary/ 
voice. Despite there being no words in his "aria", Widmann develops the melody with long note-values tying one pitch to another, conveying a strong emotional stage of sadness in the music, giving the final gesture before its death. Such an act also shows Widmann's attempt to draw his audience into an imagery "scene", preparing for a complete end of the composition and his "story".

An indication with a "cadenza-like" passage is employed in the second and fourth acts. As in in some cadenzas of conventional concerti, there is a sustaining note or chord included in other instrumental parts as accompaniment to the soloist in the Viola Concerto. In the second act the emotional expressive vocallike, lyrical melody with the use of molto rallentando, soft dynamics and pauses gradually lead to a virtuoso cadenza passage. Some previous musical gestures of the melody are also heard in the cadenza. Nevertheless, in his Viola Concerto, what Widmann does differently from the traditional concerto is that not all cadenzas appear near the end of the acts. For instance, a short toccata cadenza passage is used to begin the fourth act, giving an alternative way of introducing a cadenza in a concerto. Different musical characters such as fast repeating notes in sul ponticello, spiccato and others are employed, not only differentiating it from the passage of the previous act, but also creating tension as the music progresses.

Widmann's primary concern also includes the use of a variety of techniques to provide the work with distinctive sound colors. "I love discovering new aspects of instruments," said Widmann. ${ }^{38}$ To create intended sound colors that suit the atmospheres and moods for a fictional world in the concerto the instruments are played not only with specific instructions, but also indications throughout the score. Different sound palettes are heard in the music through a tap on the chinrest, fingerboard, shivering glissandi, un-pitched noises, a play behind the bridge, a scotch glass is used to prepare the piano, and many others. There are also microtonal notations and other indications included in the music, such as "show bow direction away from body or towards body," "plectrum glissandi between tuning pins and string attachment". Trills are used to create atmosphere; they begin with extreme slow tempo, gradually accelerando and, at times returning back to slow tempo. An example can be heard towards the end of the last section/act in the viola parts.

In addition, non-Western instrumental sound colors are explored, establishing a "utopia land" and "oriental fairytale world" of Widmann's imagination in the music. For instance, in section/act one Widmann intends to imitate sitar sound color in the solo viola by using a different instrumental notation and indication

swan\%20song\#learn-more (accessed on June 17, 2019)

38 “Jörg Widmann”, Classical-music.com, August 7, 2014; available online at http://www.classical-music.com/article/j\%C3\%B6rg-widmann (accessed on May 8, 2019) 
"Imporivisation - Klang: Indian Sitar sempre" on the score. Sitar is a plucked stringed instrument popular in northern India and is the dominant instrument in Hindustani music. ${ }^{39}$

Every decision making in Widmann's writing has a role in the music, including his introduction of climactic passages. There are two essential climatic moments that Widmann designed throughout the entire composition. Both occur towards the end of each section/act. Each climax has its unique way and purpose of drawing the attention of listeners. The first reaching of an intense peak takes place in the first section/act in high pitch registers in all instruments, and a continuously loud, speedy strumming sound of four pitches in pizzicato in solo viola. It is prepared for the up-coming major event of the piece, in which the tapping sound is to be taken over by the first arco bowing in the music. The other climactic moment is a theatrical emotional vocal scream that appears in section/act three. Widmann creatively designs the decrease of tension after the scream climax, that gradually leads the audience to section/act four.

The music begins and ends differently in sound colors. To capture the farewell moment towards the end of the music the texture grows thinner. There are no other sounds colors heard beside the strings that are gradually decrescendo in dynamics. Low register pitches are used. Widmann brings the work to a close by concluding the entire piece with fading out sound indicated al niente signs in strings.

\section{Conclusion}

The Viola Concerto demonstrates a novel way of presenting a traditional genre, and a new means of communicating with the audience. Widmann delivers ideas and new approaches through the visual and auditory senses, allowing audiences to effectively engage in the manner he designed the fictional world. The soloist walking from one point to another on the stage gives the audience a theatrical and operatic experience in the concerto. Not only does every idea and approach create forward momentum in the music, but also Widmann is able to maintain interest and dramatic tension across an entire composition. He has certainly offered a highly effective example of the interplay between music and the visual.

Indeed, the concerto demonstrates that the composer is largely inspired by his operatic interests. Widmann's music is notable for a dramatic feeling that is created through his imagination and creativity. The emotional quality, often exaggerated, is not only aural but also contains visual and somewhat theatrical effects; indications of physical movements, gestures and expressions for the soloist

${ }^{39}$ Virginia Gorlinski, "Sitar”, Encyclopedia Britannica; available online at https://www.britannica. com/art/sitar (accessed on July 3, 2019) 
are presented naturally as though Widmann is writing for an opera. Thus the audience encounters simultaneously music and action on the stage.

There are ways in which Widmann seeks a connection to the operatic genre in the Viola Concerto, engaging his listeners with a palette of colorful instrumental sounds and expressive musical language. The music takes on several roles so as to create atmosphere, emotion, dialogues, and abstract protagonists in a fictional world as Widmann describes it. Not only does he freely use whatever materials that suit his expressive purpose, but also creates imaginable sounds from instruments. His explorations in the composition also include the relation between music and sound. Music is used to depict setting, atmosphere and mood. Emotion, expressed through a scream, for example, is being "performed" by vocal sound rather than sung in words.

The sound images in the concerto give rise to a story Widmann intended to tell and interpret. At times, one also witnesses how Widmann "dialogues" with past musical material. Surprises are included, keeping the music intriguing. Mood and atmosphere are created by various compositional techniques to maintain the attention of his audience. The notion of an aria, which is common in operas, is introduced in the concerto, which reveals Widmann's eagerness to experiment with operatic writings in his orchestra music. Lyrical melodies are written similar to vocal writing, in which they are in narrow pitch range and often in long-note values.

Musically, the Viola Concert explores various musical idioms and styles, drawing parallels between past and present, between tradition and contemporary. At times it references back to the Romantic era, and at other moments to $20^{\text {th }}$ century sound experimentation. Contrasting emotions occur throughout the music; nevertheless, the emotional climax of the concerto is designed differently from other conventional works and it arrives with a loud, fury vocal scream. Although there are extreme contrasts in colors and expressions between voice and lyrical instrumental melodies, the collision between them does not disrupt the form. Widmann makes sure that the transition from one to another section/ act is smooth. The music develops through different stages of an abstract "story".

Musical dialogues are projected between instruments in natural, smooth and emotional ways through dynamic levels and expression markings. Indeed, it is not difficult to see the connection to operatic writing in the composition, despite the fact that there are no obvious opera "scenes" nor story told in the music. The composition is able to challenge our most deeply rooted assumptions concerning the concerto tradition.

Throughout the composition musical characters and sound colors are used as a tool to structure the formal design of the music. The finger tapping and 
arco bowing sounds are used to divide the composition into two main different structural divisions. Interesting dramatic sounds for creating imagery "scenes" and atmosphere are carefully worked out in different sections/acts, significantly balancing both the structural design and continuity of Widmann's abstract "story" transitioning from one to the other throughout the composition. In addition, cadenzas are experimented with and presented in ways beyond a conventional fashion of a concerto.

Climaxes are creatively employed and designed for the purpose of giving coherency between sections/acts. Various tempi, dynamic levels and vocal fury screaming are used to heighten emotion in the music, guiding the audience's attention through the composition. Widmann has developed a very personal and unique approach to composition; human voice has gained increasing importance in his compositions, including the Viola Concerto. What Widmann presents here is the musical ideas with which one is familiar from the operatic and concerto traditions.

Widmann has created a different, refreshing and intriguing way of presenting his orchestra work, which is significantly different from a conventional concerto. This gives rise to his distinctive characteristic and personal style throughout. Yet, in experimenting with a new presentation fashion in his concerto, Widmann is keeping the Concerto genre alive.

\section{The Operatic Styles in Jörg Widmann's Viola Concerto}

\section{Abstract}

This study explores Jörg Widmann's operatic compositional approach found in his Viola Concerto (2015). He has created a refreshing and intriguing way of presenting the composition that differs from a conventional concerto. In it, Widmann delivers ideas and new approaches through the visual and auditory senses, allowing audiences to effectively engage in the manner he designed of the fictional world. The music takes on several roles so as to create atmosphere, emotion, dialogues, and abstract protagonists in a "story" he designed. He makes the music as dramatic and as theatrical as possible, giving a new presentation fashion in his concerto, keeping the Concerto genre alive. 


\section{Operní styl v díle Viola Concerto Jörg Widmanna}

\section{Abstrakt}

Studie zkoumá operní skladatelský př́stup Jörg Widmanna v díle Viola Concerto (2015). Skladatel zde vytvořil osvěžující a zajímavý způsob prezentace skladby, která se liší od konvenčního koncertu. Widmann v díle přináší nápady a nové prístupy prostřednictvím vizuálních a sluchových efektů, které divákům umožňuji hlubší prožití vytvořeného fiktivního světa. Hudba má několik rolí, když zprostředkovává atmosféru, emoce, dialogy i abstraktní protagonisty v „př́běhu“, který autor sám vymyslel. Skladatel posouvá hudbu na hranici dramatických a divadelních možností, čímž formu koncertu inovuje a aktualizuje.

\section{Keywords}

Jörg Widmann; Viola Concerto; operatic style

\section{Klíčová slova}

Jörg Widmann; Viola Concerto; operní styl

Kheng K. Koay

National Sun Yat-sen University, Taiwan

kkhengk@yahoo.com; kkhengk@mail.nsysu.edu.tw 